CURRENT RESEARCH JOURNAL OF PHILOLOGICAL SCIENCES 2(12):

195-200, December 2021

DOI: https://doi.org/10.37547/philological-crjps-02-12-37

ISSN 2767-3758

(C)2021 Master Journals

Crossref doi) 81 Google

Accepted21 ${ }^{\text {th }}$ December, 2021 \& Published $26^{\text {th }}$ December, 2021

\title{
AN ANALYSIS ON FERIT EDGU'S STORIES
}

\section{Shakhnoza Karimova}

Teacher, Turkish Philology Department, Tashkent State University Of Oriental Studies, Uzbekistan

\section{ABSTRACT}

Ferit Edgu is one of the best writers of not only Turkish literature but also World literature. He has written his works in different genres such as novels, short stories, memoirs, poems and essays. The author who revealed his stories with an extraordinary structure, has become the representative of his generation. Using language, creating stories with few words is an important element in the writer's storytelling. Since the common denominator of psychology and literature is human and human behavior. It is inevitable that these two disciplines feed one another and form a resource for each other. While depicting life in his stories, he was able to reach meaning integrity by making use of very few words. In this way, he succeeded in attracting and impressing the reader with brief narratives. Existentialism, like Kafka, was evident in his stories. In this article, we tried to analyze Ferit Edgu's stories based on his language, technical elements, richness of expression and beauty concerns.

KEYWORDS: - Ferit Edgu, Hakkari, Kafka, Sait Faik, story, short story.

\section{INTRODUCTION}

Writer of short stories, novels and essays. He was born on February 24, 1936, in Istanbul. His full name is Ismail Ferit Edgu. When he was a senior student at the Painting Department of the Istanbul Academy of Fine Arts, he went to Paris and studied ceramics for six years at the Academie Feu in Paris. He continued philosophy at the Sorbonne and art history courses at the Louvre (1958-64). After completing his military service in a village of Hakkari in Beypazarl, he stayed in Paris for one more year. Returning to Istanbul a year later, he worked as a copywriter in Istanbul Management for a while. He managed the DATA Advertising
Company that he had founded, then Ada Publishing and Bedri Rahmi Art Gallery in Narmanlı Yurdu after 1977.

His first poem was published in the magazine Kaynak (1952) and his first story was published in the magazine Yeni Ufuklar (January 1954). He entered the literary world with his poems published in the magazines Kaynak (1952-53), Şairler Yaprağ (1954), Mavi (1954), Yeni Ufuklar (1962). Then he turned to the story and novel, where he was more successful. His stories, reviews and translations had started appearing in magazines such as Yeni Ufuklar, Pazar Postası, Dost (1954-59), Yeni Dergi, Papirüs, Antalya, Soyut. He has written his works in different genres such as novels, short stories, 
CURRENT RESEARCH JOURNAL OF PHILOLOGICAL SCIENCES 2(12):

195-200, December 2021

DOI: https://doi.org/10.37547/philological-crjps-02-12-37

ISSN 2767-3758

(C)2021 Master Journals

\section{Crossref do) 81 Google}

Accepted21 ${ }^{\text {th }}$ December, 2021 \& Published $26^{\text {th }}$ December, 2021

memoirs, poems and essays.

\section{Methods}

When he was 16-17 years old, he met Sait Faik's stories by chance and his literary background began to form. The stories he read from Sait Faik made him think, "You can write too" ${ }^{1}$. His first story, which was not included in his books, was published in 1953 in the journal Yeni Ufuklar. He made a name for himself in the world of literature with his poems and stories published in Kaynak, Yeni Ufuklar, Şairler Yaprağı, Vatan, Mavi, Pazar Postası ve Dost magazines. He drew attention with his articles on contemporary art and aesthetic problems that he published in Yeni Dergi, Ant, Eylem, Ataç, Papirüs, Soyut ve Yeni Ufuklar journals betweens 19501960.

Ferit Edgu perceived art as a whole with her works positioned in contradiction to her creative personality. Although he melted reality in the crucible of existential philosophy and established a harmony between content and form, he prioritized formality. The literary life of the author, who explains the universality with individuality and sociability by centering the human reality in his works, was classified as the formation period the period before Hakkari (1954-1964) and the period after Hakkari (after 1964) ${ }^{2}$. In this classification, the author's confrontation with different external realities in Hakkari, where he went as a reserve officer teacher, had a great impact. Described as the post-Hakkari period, the author accepted this birth as an ontological completion rather than a radical change in his literary life. Ferit Edgü, in an

\footnotetext{
${ }^{1}$ Deveci, Mutlu (2008). Ferit Edgü ile Sanat, Edebiyat ve Dil Üzerine Bir Söyleşi. Ada Dergisi. S.10. s. 38-42.

${ }^{2}$ Deveci, Mutlu (2012). Ferit Edgü Varoluş ve Bireyleşme. İstanbul: Sel Yayınları. s. 20
}

interview with his in 1979, defined the artist as the person who revealed with his works that this world is not the only possible one. He emphasized that the function of art is to offer a new breath, a new hope, a new voice and a more humane, truer and more genuine future to the society from which it emerged, and emphasized that art should make people conscious of the world they live in and instill a belief in change. In his stories and novels, he often and generally dealt with the mental and sexual depressions of the wealthy and intellectuals, the loneliness of people, the feeling of alienation, and unhappiness with a fantastic narrative. Acting on the view that there is no single "truth", he tried to reflect the truth in various ways in her stories. He used a simple, very clean, understandable and surprisingly harmonious language consisting of Turkish words like a melody. The author says the following about his own narration: "I have seen over and over again that language is not a tool for me, it is the basis of the work, its skeleton, everything. When you reach this point, you see that there is no point in embellishing the language, going to similes, using copious amounts of adjectives. This is without glare, without creating hollow images with the gilding of the rhetoric, without lies, as lean as possible, a straightforward narrative" ${ }^{3}$.

The author's concern to pursue the truth and the concrete world, which was felt in her first stories, also shaped the thematic fiction of later periods. Depressed, helpless, lonely, foreign, hopeless and pessimistic story characters carried traces of Edgu's mood at that time. Edgu's works belonging to the pre-Hakkari period, which started the formation period of her literary life with poetry, were positioned in the determination of imaginary and surreal elements. His works in this period, in which escapes for the search for meaning took place, he

${ }^{3}$ Edgü, Ferit (2003). Sözlü/Yazıllı. İstanbul: Yap1 Kredi Yayınları. s. 23 
CURRENT RESEARCH JOURNAL OF PHILOLOGICAL SCIENCES 2(12):

195-200, December 2021

DOI: https://doi.org/10.37547/philological-crjps-02-12-37

ISSN 2767-3758

(C)2021 Master Journals

Crossref do

gil Google

Accepted21 ${ }^{\text {th }}$ December, 2021 \& Published $26^{\text {th }}$ December, 2021

looked at the human reality on the plane of universal references. In his stories and novels about the East after Hakkari, Edgu tried to reflect what happened as it was, not to approach critically and not to negate the people. While conveying his unbiased view how to destroy different realities in the East with self-consciousness, he examined the conflicts centered on the intellectual man - people, urban - peasant, state - people. Edgu's people, who highlight the existential themes that are the source of the individual's temporal and spatial captivities such as social injustice, degeneration, rebellion, depression/anxiety, the absurdity of life, the search for meaning, homelessness, desperation, miscommunication and loneliness were appeared reminiscent of Kafka's heros who were impossible with states of existence, resisting in vain, depressed in the dimension of nothingness, looking hopeless at the future.

In the first, four story books: Kaçkınlar, Bozgun, Av and Bir Gemide, the themes such as a philosophical crisis, nothingness of the individual in the world, closing on oneself, questioning himself existence were written. Especially the storybook Bir Gemide consisted of dense and detailed stories. This book was often parallels the existentialism, depression, and the main themes that they narrate with motifs of the surreal of Generation storytellers in the 1960s. The stories in Çı̆̆lık, with their language and fiction, did not turn to the event but to the language itself. In general, in Ahmet Oktay's words, "The tension in his stories appeared at the level of language" ${ }^{4}$. In the book called Eastern Stories, there were stories that show how much was affected by the east, how the geographical conditions and the human characters were determined their own image world. In these stories, the form and language became as simple as possible. The

${ }^{4}$ Oktay, Ahmet (1960). Yazınımız Üstüne Notlar II. Dost yayınları. s. 22. storybook named İşte Deniz, Maria consisted of the stories that were written as dialogue. In the storybook named Do Sesi, he knitted eighty-three stories divided into four sections within the framework of basic themes around a narrator who is considered the most basic actor of the narrative. In these stories, where this narrator is sometimes in the first person and sometimes in the third person, he fictionalized two-person, placeless and undescribed stories.

The expression "the human being (ego) who cannot figure out the whole" indicates that he is a person who asks questions and "trying to grasp all the parts of reality" when he cannot conclude chasing the "why". The short story, the short story form, is an effort to focus on this 'piece', a slice of life. Ferit Edgu's short stories that deal with a 'moment' are not few in number. Among these, the story named Üç Düş is an exquisite example of her mastery of his editing, versatile optics technique. By putting himself in the role of a bird, a hunter and a dog, he portrayed the event of the "falling moment" and saved the story form from turning into a fairy tale by placing that moment in a 'dream'.

"Reaching the deep meaning of the visible world and life shows the artist and the writer stepping into the abstract by elevating them to philosophy. Ferit Edgu's 'minimal storytelling' is also, in a sense, a departure to the abstract." 5

In her first storybook Kaçkınlar (1959), he created schizophrenic types with their depressive personalities and expressed their existence in a "nightmare / Kafkaesque atmosphere" ${ }^{6}$. In her second work, Bozgun (1962), he talked about the

\footnotetext{
5 Aytaç, Gürsel (2004). Ferit Edgü’nün Öykücülüğü. Heceöykü dergisi. Y1l sayıs1 1. s.84.

${ }^{6}$ Ecevit, N. Y1ldız (1992). Kurmaca Bir Dünyadan. Ankara: Gündoğan Yayınları. s. 105
} 
CURRENT RESEARCH JOURNAL OF PHILOLOGICAL SCIENCES 2(12):

195-200, December 2021

DOI: https://doi.org/10.37547/philological-crjps-02-12-37

ISSN 2767-3758

(C)2021 Master Journals

\section{Crossref doi) 8 Google}

Accepted21 ${ }^{\text {th }}$ December, 2021 \& Published $26^{\text {th }}$ December, 2021

introverted individual's realization of her groundlessness while trying to grasp himself. Consisting of short stories between 1953 and 1967, the storybook Av was published in 1967. He expressed effort to get rid of the traces of the past that permeates the present in the storybook Av, which dreams and reality were melted in the same pot. In the story Bir Gemide (1978), for which won the 1979 Sait Faik Story Award, he talked about the miscommunications arising from the disconnection between the individual, the society, and the deterioration in the value system. This work attracted attention with its combination of language and fantastic elements. 10 of the total 21 short stories in the storybook Ç.ğlık (1982), which consists of summoning the individual to his own being and combining loud and silent screams in the context of dream and reality, waited for a long time to be completed by the reader. In fact, these ten stories with the title of Parts were completed and published in the book titled Parts prepared by Baran Güzel in 2017. Ferit Edgu brought together the first examples of the "short story" ${ }^{7}$ genre in Turkish literature, in which the language is distilled and the narration/transmission of a single moment, in his work Binbir Hece (1991). In these stories, where there is no event and description, instead of them instant situations, the author tried to capture the essence of the being called language. In the storybook Doğu Öyküleri (1995), he expressed that people, who try to exist in the negative of physical, economic and social conditions, were attached to the fateful one, with the necessities of faith and deprivation / poverty. The short stories in the work, in which the eastern reality was told, were shaped in relation to the novels of the author in terms of thematic, spatial and temporal fiction. In the five short stories in İşte Deniz, Maria (1999), where the

7 Korkmaz, Ramazan., Deveci, Mutlu (2017). Türk Edebiyatında Yeni Bir Tür: Küçürek Öykü. Ankara: Akçağ Yayınları. s.12. usual story patterns were broken, he reflected the understanding of the story in the 1960s. Existential situations of daily life were exhibited in the short stories included in the Very Short Stories sub-title of the work. The ten short stories included in the storybook Devam (2001) were composed by his writings between 1960 and 1967. In the stories the conflict of social values and self-values that the individual cannot internalize was discussed. In the storybook Do Sesi (2002), which many stories were without a story, in which death, life and the absurd were told, everyday life was conveyed through an existentialist shape. In these stories, the phenomena of the individual trying to exist with their depressions, which were revealed by nothing, drew attention. While depicting life in his stories, he was able to reach meaning integrity by making use of very few words. In this way, he succeeded in attracting and impressing the reader with brief narratives. Existentialism, like Kafka, was evident in his stories.

The storybook Nijinsky Öyküleri (2007) was the product turned into Short Stories of the famous ballet dancer / dance artist Vaclav Nijinsky's the diaries that he kept in Switzerland in 1919. Ferit Edgu who wrote her first and last play trial works in Paris (1961-1962), the content of this work was expressing: "A man was talking to himself in a hole in the middle of the stage, occasionally saying a word or two to the phone that was ringing next to him and hanging up. As he continued his monologue, he was slowly sinking into the pit he was in, and towards the end he could not answer the phone" ${ }^{8}$. The common component of the selfcalls in Ferit Edgu's short stories opens up the breakthroughs towards the creation of the individual self. In the short story called Işık, the call embodied by the image of light refers to the

${ }^{8}$ Edgü, Ferit (2003). Sözlü/Yazılı. İstanbul: Yap1 Kredi Yayınları. s. 72. 
CURRENT RESEARCH JOURNAL OF PHILOLOGICAL SCIENCES 2(12):

195-200, December 2021

DOI: https://doi.org/10.37547/philological-crjps-02-12-37

ISSN 2767-3758

(C)2021 Master Journals

\section{Crossref do) 81 Google}

Accepted21 th December, 2021 \& Published $26^{\text {th }}$ December, 2021

possibility of the individual in the stage of selfexploration:

"Koridorun ucundaki ışığı görüyor musun?

Tabii görüyorum.

Öyleyse niçin yazmıyorsun?” 9 (Do Sesi, “Işık”, s.73)

("Do you see the light at the end of the hallway?

Of course, I see.

So why don't you write?")

The story seems to be constructed as an external dialogue between a story figure who is conscious of its possibilities and another story figure in the position of a closed being who is not conscious of its possibilities. In fact, in the story reflecting the transformation of a monologue into a dialogue, the Other/non-I (non ego) are in conversation.

The call made with the light image invites the usual life being to be himself, revealing his closure. Thus, the ego, which is directed to know and understand itself, is invited to position its essence. The corridor referent, which expresses the intersection/union of different places at the same point in a spatial sense, indicates a connection point. It also carries the image of distance/distance within it. In this context, the light at the end of the corridor is the object of the call for the enlightenment of the individual. The individual, who turns to himself with the bright connotation of the light image, will take action to reveal his own values. The individual, who cannot act despite seeing the light and knowing its potential/possibility, is invited to writing, another call image that has the same referent as enlightenment and light: "Through the act of writing, one's experience with oneself intensifies" ${ }^{10}$. If to write is to live; the story character, who is called to the act of writing, will reveal, understand

\footnotetext{
${ }^{9}$ Edgü, Ferit (2002), Do Sesi, "Işık", 1. bs. İstanbul: Yap1 Kredi Yay. s.73.

${ }^{10}$ Foucault M vd. (1999), Kendini Bilmek, (Çev. Gül Çağalı Güven), 1. bs. İstanbul: Om Felsefe Yay. s. 42.
}

and create himself thanks to this call. In Edgu's stories, the idea of meaninglessness, boredom and nothingness is dominant. The texts of existentialist writers, which were heavily translated at that time, had a great influence on this. A character that he himself does not know why he was put in a cell, a man peeing on the wall of a restaurant, or a passenger on that ship in the story Bir Gemide who is unknown at that moment and whose direction is uncertain, tries to show the meaninglessness of life and existence with its oddities. Kafka's influence in Edgu should be mentioned in particular. The characters find themselves in some strange and mysterious events, do not know what to do and ask simple questions. For example, a hero of story looking for his house comes to a place called "Yitik Bokpüsürleri Arama Odası" and asks an officer where the street he lives in is. However, the man says, "There is no such place in this city."

The hero of the story "Sanri" is also condemned to "paint this piece on that wall" ${ }^{11}$. Ferit Edgu, unlike Demir Özlü, tried to make this meaningless emphasis more impressive with some symbols and event narrations reminiscent of Kafka, instead of constantly whining about the "meaningless" world he was in. ${ }^{12}$ In the chapter titled "Odada" of Edgu's book Kaçkınlar, he describes a cramped room filled with chairs, a table and a bed. A character who fights with a huge rat in the room and finally realizes that there is no escape from it... . In Ferit Edgu's stories, we see that the existential distress and depression become evident with the huge rat in the house, with a wound that suddenly appears on the body as in Sanri, or with the unbearable smells rising above the city.

\footnotetext{
${ }^{11}$ Edgü, Ferit (2009). Kaçkınlar, Sel Yayıncılık, İstanbul, 2009, s. 17.

${ }^{12}$ Erdal,Cihan (2016). Ferit Edgü Öykücülüğü: Suskunluk ve Yazmak Arasında, MSGSÜ Sosyal Bilimler Dergisi Say1 13. s. 70-77.
} 
CURRENT RESEARCH JOURNAL OF PHILOLOGICAL SCIENCES 2(12):

195-200, December 2021

DOI: https://doi.org/10.37547/philological-crjps-02-12-37

ISSN 2767-3758

(C2021 Master Journals

Crossref do

81 Google

Accepted21 ${ }^{\text {th }}$ December, 2021 \& Published $26^{\text {th }}$ December, 2021

In the story "Odada" in the book Kaçkınlar, rats are chosen as a kind of symbol that conveys the narrator's distress. Rats also haunt the inner world of the character, who perceives the outside world as a hell.

\section{Conclusion}

Ferit Edgu, whose literary background began to form when he was 16-17 years old, when he met Sait Faik's stories by chance. He stated that it develops in two branches, the understanding that tries to grasp the truth through language and the understanding that the extraordinary (fantastic) element is guiding ${ }^{13}$. The stories he read from Sait Faik made him think, "You can write too" ${ }^{14}$. Influenced by existentialism, impressionism, surrealism and minimalism of the visual arts, the author expanded the limitations of their meanings by transforming words into sentences in his works, where he created aesthetics with philosophical content. This feature, which was an indicator of his power to use language, became the distinguishing feature of his authorship. The author who revealed his stories with an extraordinary structure, has become the representative of his generation. Using language, creating stories with few words is an important element in the writer's storytelling. Since the common denominator of psychology and literature is human and human behavior.

Ferit Edgu, who synthesized the line of Sabahattin Ali, Sadri Ertem, Memduh Şevket Esendal, Sait Faik Abasıyanık with individual initiatives and sociocultural influences of the age was influenced by

${ }^{13}$ Edgü, Ferit (2003). Sözlü/Yazıll. İstanbul: Yapı Kredi Yayınları. s.60.

${ }^{14}$ Deveci, Mutlu (2008). "Ferit Edgü ile Sanat, Edebiyat ve Dil Üzerine Bir Söyleşi”. Ada Dergisi. S.10.38-42. authors from world literature such as Kafka, Rimbaud, Lautreamont, Marguis de Sade, Beckett, Sartre, Michaux, Gogol, Rebelias and Chekhov. The author, who draws attention with his significant influence on today's young writers, has also taken his place in world literature with his works translated into many languages.

\section{REFERENCES}

1. Aytaç, Gürsel. (2004). Ferit Edgü'nün Öykücülüğü. Heceöykü dergisi. Yıl sayısı 1.

2. Deveci, Mutlu (2008). "Ferit Edgü ile Sanat, Edebiyat ve Dil Üzerine Bir Söyleși". Ada Dergisi. S.10.38-42.

3. Deveci, Mutlu (2012). Ferit Edgü Varoluş ve Bireyleşme. İstanbul: Sel Yayınları.

4. Ecevit, N. Yıldız (1992). Kurmaca Bir Dünyadan. Ankara: Gündoğan Yayınları.

5. Edgü, Ferit (2002), Do Sesi, "Işık", 1. bs. İstanbul: Yapı Kredi Yay.

6. Edgü, Ferit (2003). Sözlü/Yazılı. İstanbul: Yapı Kredi Yayınları.

7. Edgü, Ferit (2009). Kaçkınlar, İstanbul: Sel Yayıncilık.

8. Erdal,Cihan (2016). Ferit Edgü Öykücülüğü: Suskunluk ve Yazmak Arasında, MSGSÜ Sosyal Bilimler Dergisi Sayı 13. s. 70-77.

9. Foucault M vd. (1999), Kendini Bilmek, (Çev. Gül Çağalı Güven), 1. bs. İstanbul: Om Felsefe Yay.

10. Korkmaz, Ramazan., Deveci, Mutlu (2017). Türk Edebiyatında Yeni Bir Tür: Küçürek Öykü. Ankara: Akçağ Yayınları.

11. Oktay, Ahmet (1960). Yazınımız Üstüne Notlar II. Dost yayınları. 